ORIG I NAL ARTICLES

99 Influenza Vaccination Among Registered Nurses: Information Receipt, Knowledge, and Decision-Making at an Institution With a Multifaceted Educational Program • Cori L. Ofstead, MSPH; Sharon J. Tucker, PhD, RN; Timothy J. Beebe, PhD; Gregory A. Poland, MD

107 Commentary: Improving Rates of Influenza Vaccination Among Healthcare Workers: Educate; Motivate; Mandate? - Thomas R. Talbot, MD, MPH

111 Use of a Pandemic Preparedness Drill to Increase Rates of Influenza Vaccination Among Healthcare Workers • Jennifer L. Kuntz, MS; Stephanie Holley, BSN; Charles M. Helms, MD, PhD; Joseph E. Cavanaugh, PhD; Jeff Vande Berg, MS; Loreen A. Herwaldt, MD; Philip M. Polgreen, MD, MPH

116 Extended Use of Urinary Catheters in Older Surgical Patients: A Patient Safety Problem? • Heidi L. Wald, MD; Anne M. Epstein, PhD; Tiffany A. Radcliff, PhD; Andrew M. Kramer, MD

Salvage of Long-Term Central Venous Catheters During an Outbreak of Pseudomonas putida and Stenotrophomonas maltophilia Infections Associated With Contaminated Heparin Catheter-Lock Solution - M. Beatriz Souza Dias, MD, PhD; Alina Bernardes Habert, MD; Vera Borrasca, RN; Valeska Stempliuk, RN, PhD; Aina Ciolli, RN; M. Rita E. Araújo, MD; Silvia F. Costa, MD, PhD; Anna S. Levin, MD, PhD

Randomized Controlled Trial and Meta-analysis of Oral Decontamination with 2\% Chlorhexidine Solution for the Prevention of Ventilator-Associated Pneumonia - Hutsaya Tantipong, MD; Chantana Morkchareonpong, MD; Songyod Jaiyindee, MD; Visanu Thamlikitkul, MD

137 Measuring Acceptable Treatment Failure Rates for Community-Acquired Pneumonia: Potential for Reducing Duration of Treatment and Antimicrobial Resistance - Keith S. Kaye, MD, MPH; Anthony D. Harris, MD, MPH; Jay R. McDonald, MD; Larry J. Strausbaugh, MD; Eli Perencevich, MD, MS; Infectious Diseases Society of America Emerging Infections Network

143 Importance of Bacterial Burden Among Methicillin-Resistant Staphylococcus aureus Carriers in a Long-Term Care Facility • Nimalie D. Stone, MD; Donna R. Lewis, MSN; H. K. Lowery, MS; Lyndsey A. Darrow, BS; Catherine M. Kroll, MPH; Robert P. Gaynes, MD; John A. Jernigan, MD, MS; John E. McGowan, Jr., MD; Fred C. Tenover, PhD; Chesley L. Richards, Jr., MD, MPH

149 Risk of Hand or Glove Contamination After Contact With Patients Colonized With Vancomycin-Resistant Enterococcus or the Colonized Patients' Environment - Mary K. Hayden, MD; Donald W. Blom, BSN; Elizabeth A. Lyle, AB; Charity G. Moore, PhD; Robert A. Weinstein, MD

Patient Attitudes Regarding Participation in Studies of Antimicrobial Resistance • Pam Tolomeo, MPH, CCRP; Mary Wheeler, CCRP; Joshua P. Metlay, MD, PhD; Katrina Armstrong, MD; Neil O. Fishman, MD; Warren B. Bilker, PhD; Ebbing Lautenbach, MD, MPH, MSCE

160 Clinical and Economic Consequences of Failure of Initial Antibiotic Therapy for Hospitalized Patients With Complicated Skin and Skin-Structure Infections - John Edelsberg, MD, MPH; Ariel Berger, MPH; David J. Weber, MD, MPH; Rajiv Mallick, PhD; Andreas Kuznik, PhD; Gerry Oster, PhD

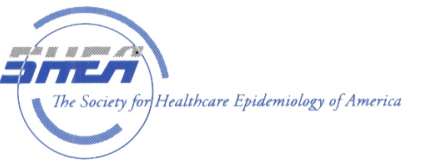




\section{Coming Soon}

\section{From Baxter Healthcare Corporation:}
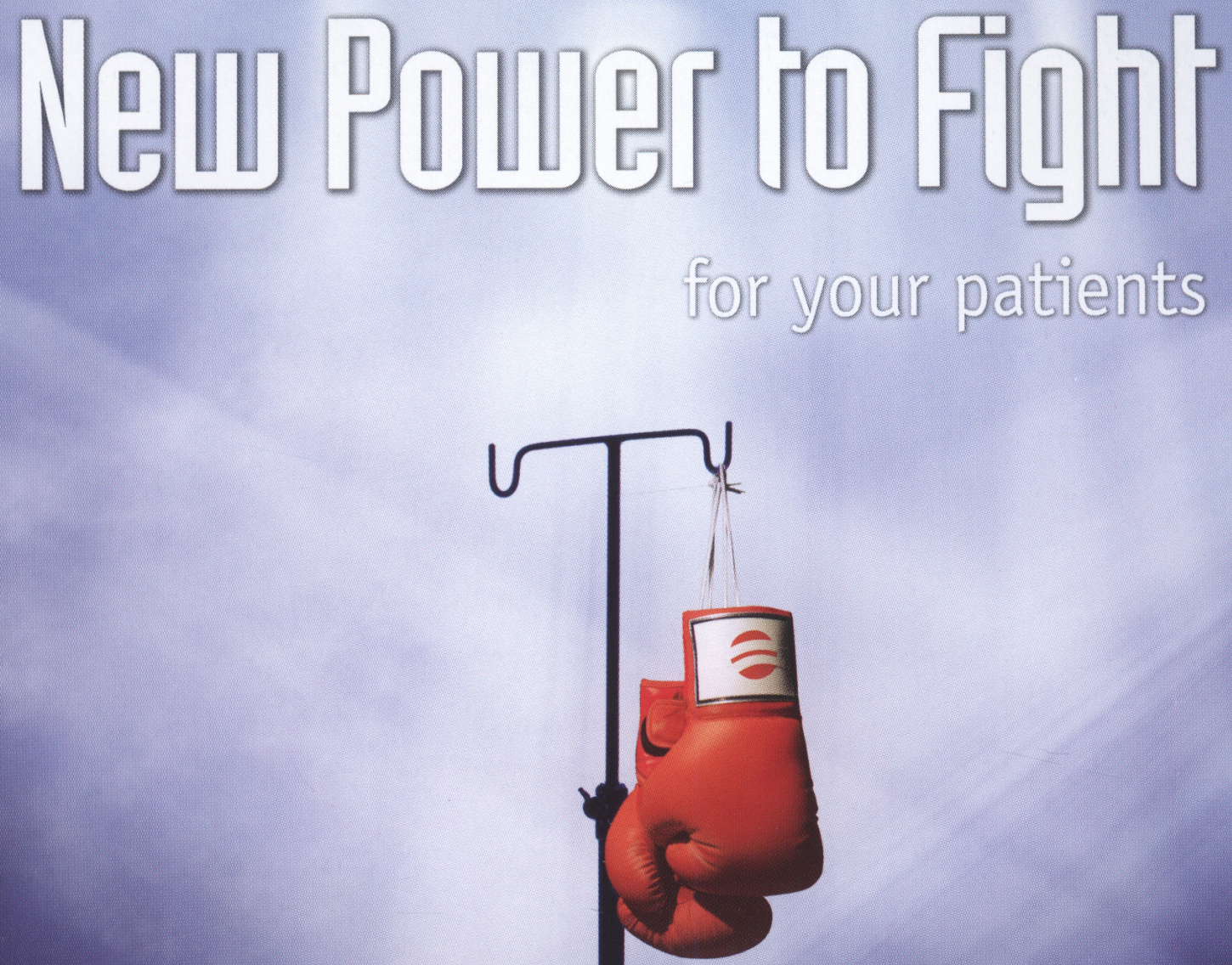

Visit www.newpowertofight.com

\section{Options at work.}




\section{INFECTION CONTROL \& HOSPITAL EPIDEMIOLOGY}

VOLUME 29 , NUMBER 2

CONTENTS CONTINUED FROM COVER

\section{CONCISE COMMUNICATIONS}

170 Receptivity to Mandatory Influenza Vaccination Policies for Healthcare Workers Among Registered Nurses Working on Inpatient Units - Gregory A. Poland, MD; Cori L. Ofstead, MSPH; Sharon J. Tucker, PhD), RN; Timothy J. Beebe, $\mathrm{PhD}$

House Staff Attitudes About Influenza Vaccination After Participation in a Clinical Trial to Improve Vaccination of Hospital Patients • Javier Cabello, MD; Krishna Das, MD; William E. Trick, MD; Mary N. Gerard, MD; Marjorie Charles-Damte, RN

177 Around-the-Clock, Rapid Diagnosis of Influenza by Means of Membrane Chromatography Antigen Testing Confirmed by Polymerase Chain Reaction - Anna C. Nilsson, MD; Birgitta Alemo; Per Björkman, MD, PhD; Lena Dillner, MD, PhD; Åsa Melhus, MD, PhD; Berit Nilsson; Anders Widell, MD, PhD

Macrolide and Clindamycin Resistance in Staphylococcus aureus Isolates and Antibiotic Use in a Veterans Affairs Medical Center • Rohit Modak, MD; David Ross, MD, PhD; Virginia L. Kan, MD

Medical Students' Exposure to Bloodborne Pathogens in the Operating Room: 15 Years Later • Connie J. Chen, BS; Rachel Gallagher, MD; Linda M. Gerber, PhD; Lewis M. Drusin, MD, MPH; Richard B. Roberts, MD)

\section{LETTERS TO THE EDITOR}

Employee Thoughts on Influenza Vaccine: Here We Go Again - Noreen H. Chan-Tompkins, PharmD; Andrew Sahud, MD; Deborah Pucci, RN, BSN, CCM; Cheryl Herbert, RN, CIC

187 Is Diarrhea Enough to Assess the Severity of Clostridium difficile-Associated Disease? •

M. Raffat Jaber, MD; Mark Reeves, MD, PhD; James Couperus, MD

189 Reply to Jaber et al. - Erik R. Dubberke, MD; Justin Sadhu, MD; Robert Gatti, BS; Kimberly A. Reske, MPH; John F. DiPersio, MD, PhD; Steven M. Devine, MD; Victoria J. Fraser, MD

190 Efficacy of Sodium Hypochlorite-Based Disinfectants Against Clostridium difficile Spores • Joan Holtschlag, BS

191 Reply to Holtschlag - Warren N. Fawley, PhD; Sarah Underwood, BSc; Jane Freeman, PhD; Simon D. Baines, PhD; Katie Saxton, BSc; Keith Stephenson, PhD; Robert C. Owens, Jr., MD; Mark H. Wilcox, MD

Should Test Methods for Disinfectants Use Vertebrate Viruses Dried on Carriers to Advance Virucidal Claims? - M. Khalid Ijaz, DVM, PhD; Joseph Rubino, BA, MA 


\section{An Official Publication of the Society for Healthcare Epidemiology of America}

EDITOR

Suzanne F. Bradley, MD • Ann Arbor, MI

\section{DEPUTY EDITOR}

Carol A. Kauffman, MD • Ann Arbor, MI

\section{SENIOR ASSOCIATE EDITORS}

C. Glen Mayhall, MD $\bullet$ Galveston, TX

Gina Pugliese, RN, MS $\bullet$ Chicago, IL

William Schaffner, MD $\bullet$ Nashville, TN

\section{ASSOCIATE EDITORS}

Ebbing Lautenbach, MD, MPH • Philadelphia, PA

Preeti N. Malani, MD, MSJ • Ann Arbor, MI

David Weber, MD, MPH $\bullet$ Chapel Hill, NC

\section{STATISTICS CONSULTANT}

Rodney L. Dunn, MS • Ann Arbor, MI

SECTION EDITOR FOR GUIDELINES, POSITION PAPERS, AND INVITED REVIEWS

Carol Chenoweth, MD • Ann Arbor, MI

\section{MANAGING EDITOR}

Gordon Rudy, PhD, ELS • Chicago, IL

\section{PAST EDITORS}

\section{Infection Control}

Richard P. Wenzel, MD, 1980-1990 (vols. 1-11) Infection Control and Hospital Epidemiology Richard P. Wenzel, MD, 1991-1992 (vols. 12 and 13) Michael D. Decker, MD, 1993-2001 (vols. 14-22) Barry M. Farr, MD, 2002-2004 (vols. 23-25) William R. Jarvis, MD, 2005-2006 (vols. 26 and 27)

\section{EDITORIAL ADVISORY BOARD}

Miriam Alter, $\mathrm{PhD}, \mathrm{MD} \cdot$ Atlanta, GA Lennox Archibald, MD, FRCP • Alachua, FL Hilary Babcock, MD • St. Louis, MO Elise M. Beltrami, MD, MPH - Decatur, GA David Birnbaum, $\mathrm{PhD}, \mathrm{MPH} \cdot$ Sidney, British Columbia

Christian Brun-Buisson, MD - Creteil, France John P. Burke, MD • Salt Lake City, UT David P. Calfee, MD, MS $\bullet$ New York, NY Yehuda Carmeli, MD, MPH - Tel Aviv, Israel Sara E. Cosgrove, MD, MS - Baltimore, MD Donald E. Craven, $\mathrm{MD} \cdot$ Burlington, $\mathrm{MA}$ Burke A. Cunha, MD $\cdot$ Mineola, NY Erika D'Agata, MD, MPH - Boston, MA Patch Dellinger, $\mathrm{MD} \cdot$ Seattle, WA Daniel Diekema, MD • Iowa City, IA Charles E. Edmiston, Jr., PhD • Milwaukee, WI Theodore C. Eickhoff, MD - Denver, CO Martin S. Favero, $\mathrm{PhD} \cdot$ Irvine, $\mathrm{CA}$ Richard A. Garibaldi, MD - Farmington, CT Petra Gastmeier, MD $\cdot$ Hanover, Germany Dale N. Gerding, MD $\bullet$ Hines, IL Donald A. Goldmann, MD • Boston, MA Anthony D. Harris, MD, MPH $\bullet$ Baltimore, MD David K. Henderson, MD • Bethesda, MD Loreen A. Herwaldt, MD $\bullet$ Iowa City, IA Peter N. R. Heseltine, MD • San Juan, CA Karen Hoffmann, RN, CIC, MS - Chapel Hill, NC Janine Jagger, $\mathrm{MPH}, \mathrm{PhD} \cdot$ Charlottesville, VA John A. Jernigan, MD, MS • Atlanta, GA James T. Lee, MD, PhD - St. Paul, MN L. Clifford McDonald, MD - Atlanta, Georgia Allison McGeer, MD • Toronto, Ontario
Leonard A. Mermel, DO, ScM • Providence, RI Robert R. Muder, MD • Pittsburgh, PA Carlene A. Muto, MD, MS - Pittsburgh, PA Joseph M. Mylotte, MD, CIC - Buffalo, NY David L. Paterson, MBBS, FRACP • Pittsburgh, PA Jan Evans Patterson, MD • San Antonio, TX Sindy M. Paul, MD • Yardley, PA

David A. Pegues, MD - Los Angeles, CA Didier Pittet, MD, MS • Geneva, Switzerland Michael A. Pfaller, MD - Iowa City, IA Gina Pugliese, RN, MS • Chicago, IL Isaam Raad, MD $\cdot$ Houston, TX Jordi Rello, MD, PhD - Tarragona, Spain Manfred L. Rotter, MD, DipBact • Vienna, Austria Henning Rüden, MD • Berlin, Germany William A. Rutala, PhD, MPH • Chapel Hill, NC Lisa Saiman, MD, MPH $\bullet$ New York, NY William E. Scheckler, MD • Madison, WI Lynne M. Sehulster, $\mathrm{PhD} \cdot$ Atlanta, GA John A. Sellick, DO • Amherst, NY Kent Sepkowitz, MD • New York, NY Andrew E. Simor, MD - Toronto, Ontario Philip W. Smith, MD • Omaha, NE Denis W. Spelman, MD • Prahan, Victoria, Australia Jeffrey R. Starke, MD $\bullet$ Houston, TX Janet E. Stout, PhD - Pittsburgh, PA Clyde Thornsberry, PhD • Franklin, TN William Trick, MD $\cdot$ Chicago, IL Antoni Trilla, MD, PhD • Barcelona, Spain Robert A. Weinstein, MD - Chicago, IL Andreas Widmer, MD, MS • Basel, Switzerland Marcus Zervos, MD • Royal Oak, MI
Infection Control and Hospital Epidemiology (ISSN 0899-823X) is published monthly by the University of Chicago Press, 1427 E. 60th St., Chicago, IL 60637-2954 (http:// www.journals.uchicago.edu/ICHE/). The editorial office is in Chicago, Illinois.

\section{Editorial Office}

Communications should be addressed to the Editor, Infection Control and Hospital Epidemiology, 1427 E. 60th St., Chicago, IL 60637-2954; (e-mail: iche@press.uchicago.edu; telephone: 773-702-2448, fax: 773-753-4247). Contributors should consult the Information for Authors, which is available at the journal's Web site.

\section{Advertising}

Please direct advertising inquiries to Journals Advertising, University of Chicago Press, 1427 E. 60th St., Chicago, IL 60637 (e-mail: thill@press.uchicago.edu; telephone: 773-7028187; fax: 773-702-0172). Publication of an advertisement in Infection Control and Hospital Epidemiology does not imply endorsement of its claims by the Society for Healthcare Epidemiology of America, by the Editor, or by the University of Chicago. Correspondence regarding advertising should be addressed to the advertising office in Chicago.

\section{Permissions}

Articles may be copied or otherwise reused without permission only to the extent permitted by Sections 107 and 108 of the US Copyright Law. Permission to copy articles for personal, internal, classroom, or library use may be obtained from the Copyright Clearance Center (http://www.copyright.com). For all other uses, such as copying for general distribution, for advertising or promotional purposes, for creating new collective works, or for resale, please contact the Permissions Coordinator, Journals Division, University of Chicago Press, 1427 E. 60th St., Chicago, IL 60637 (e-mail: journalpermissions@press.uchicago.edu; fax: 773-834-3489). Articles in the public domain may be used without permission, but it is customary to contact the author.

\section{Subscriptions}

Subscription rates for 2008 are $\$ 164$ for individuals and $\$ 386$ for institutions. Additional rates for non-US subscribers and reduced rates for fellows, residents, and students are available at http://www.journals.uchicago.edu/ICHE. Subscription agent for Japan: Kinokuniya Company, Ltd. Individuals have the option to order directly from the University of Chicago Press. Single copy rates: individuals $\$ 17$; institutions $\$ 38$.

Please direct subscription inquries, requests for back issues, and address changes to Journals Division, University of Chicago Press, P.O. Box 37005, Chicago, IL 60637 (e-mail: subscriptions@press.uchicago.edu; telephone: 773-753-3347 or toll-free in the United States and Canada 877-705-1878; fax: 773-753-0811 or toll-free 877-705-1879).

Postmaster: Send address changes to Infection Control and Hospital Epidemiology, University of Chicago Press, P.O. Box 37005, Chicago, IL 60637-2954.

Periodicals postage paid at Chicago, Illinois, and at an additional mailing office.

Published by the University of Chicago Press, Chicago, Illinois. 2008 by the Society for Healthcare Epidemiology of America. All rights reserved. This publication is printed on acid-free paper. 


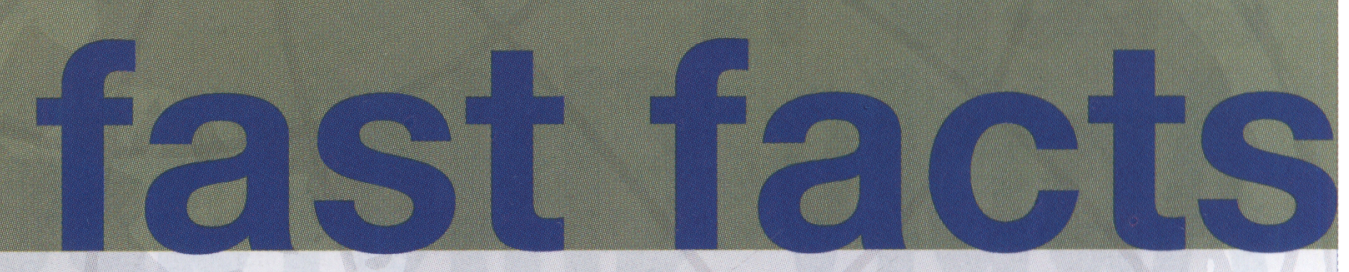

\section{www.GlobalHealthReporting.org}

\section{Search for Information on HIV/AIDS, Tuberculosis and Malaria.}

GlobalHealthReporting.org helps researchers, journalists, policy makers and NGOs efficiently sort through the latest and most accurate information on HIV/AIDS, tuberculosis and malaria. The site is updated daily and provides:

news summaries of the latest legislative, political, and scientific developments in malaria, TB, HIV/AIDS and global health.

$\rightarrow$ reference libraries and the latest information and statistics.

new and noteworthy reports, articles and resources.

$=\triangle$ Sign up for emails to receive summaries of the latest news on global health and a weekly update on new reports, resources and upcoming events. www. GlobalHealthReporting.org/email

\section{GlobalHealthFacts.org}

A new interactive database providing up-to-date and easy-to-access data by country on HIVIAIDS, TB and malaria and other key health and socio-economic indicators. The data are displayed in tables, charts and color-coded maps and can be downloaded for custom analyses. www.GlobalHealthFacts.org

GlobalHealthReporting.org is a project operated by the

Kaiser Family Foundation with major support from the Bill \& Melinda Gates Foundation.

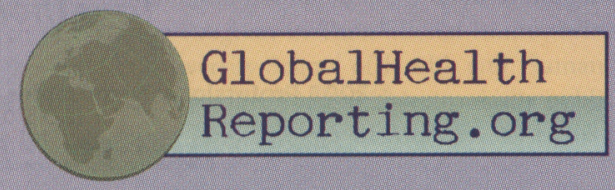

The Kaiser Family Foundation is a non-profit, private operating foundation dedicated to providing information and analysis on health care issues to policymakers, the media, the health care community, and the general public. The Foundation is not associated with Kaiser Permanente or Kaiser Industries. 

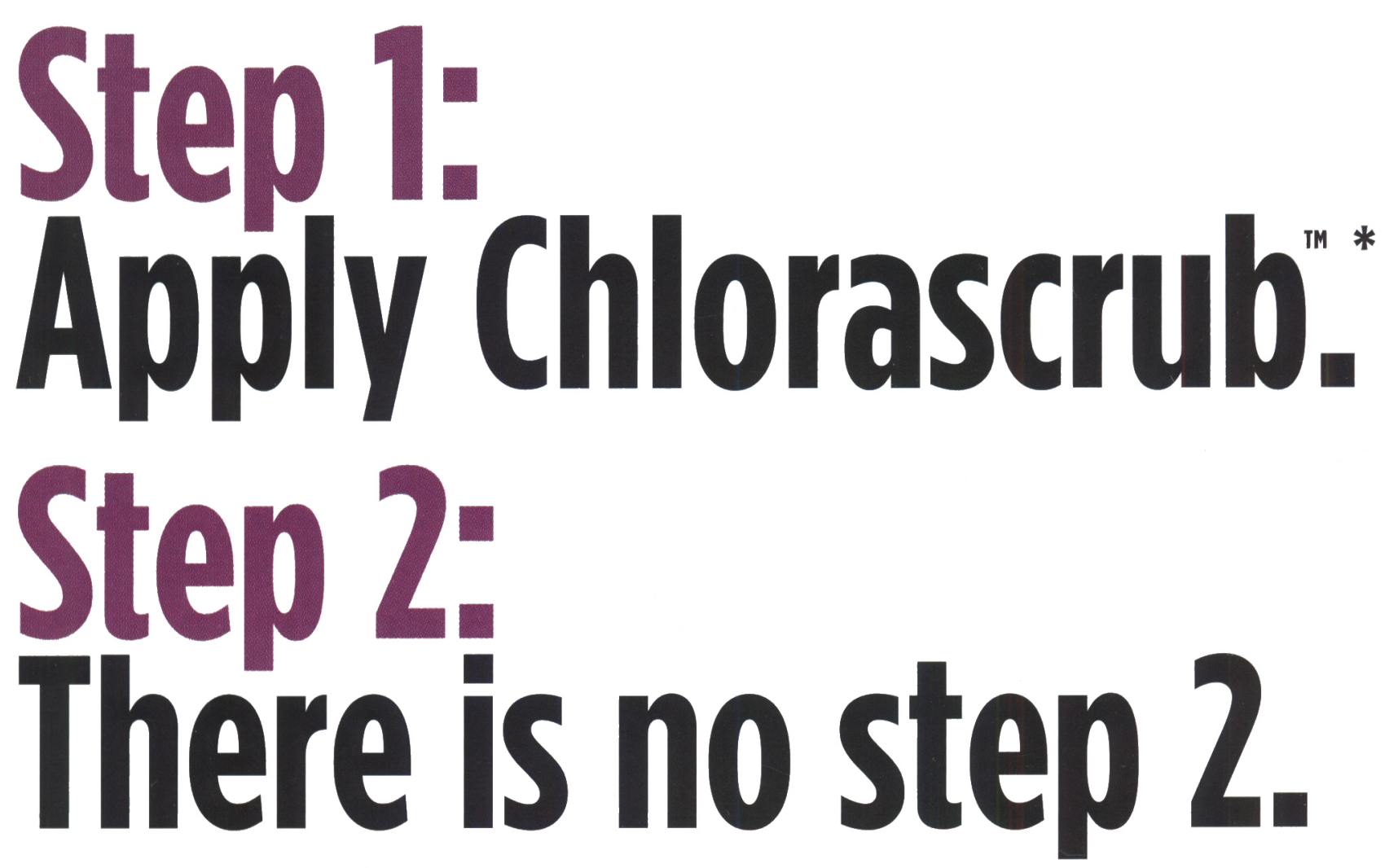

At Professional Disposables International, Inc.(PDI), we believe quality should be efficacy and efficiency. We designed Chlorascrub" to deliver both.

It's the first and only FDA approved Chlorhexidine 3.15\%(w/v) with Isopropyl Alcohol 70\%(v/v) combination skin antiseptic. A smart alternative to complicated and messy skin preps.

Finally, time-saving ease and convenience meets clinically proven efficacy.

PDI. Caring more about healthcare.

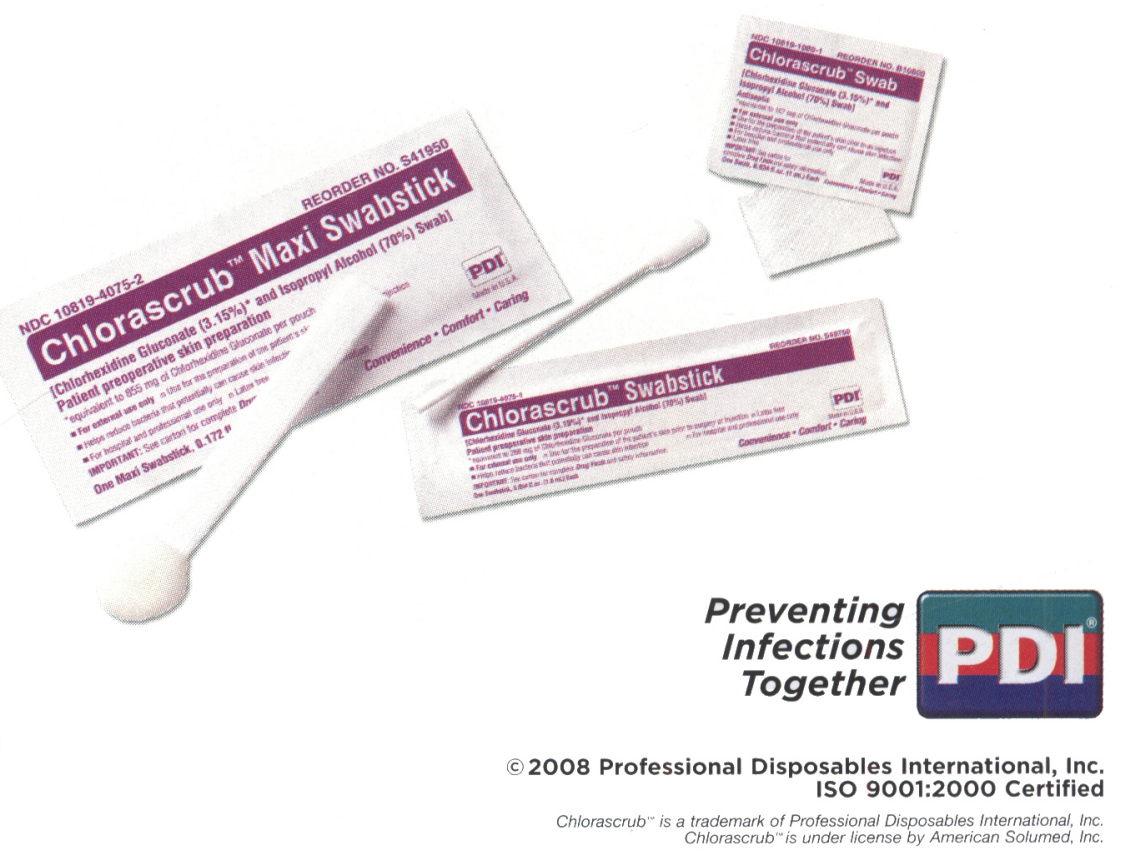

Take the next step.

Call 1-800-999-6423 to learn more or visit pdipdi.com

*See product for complete directions for use. 